Article

\title{
A Longitudinal Study of the Impact of Corporate Social Responsibility on Firm Performance in SMEs in Zambia
}

\section{Progress Choongo}

Department of Management and Organization, Faculty of Economics and Business Administration, VU University Amsterdam, De Boelelaan 1105, 1081 HV Amsterdam, The Netherlands; p.choongo@vu.nl or pchoongo2003@yahoo.com

Received: 30 April 2017; Accepted: 21 July 2017; Published: 26 July 2017

\begin{abstract}
The aim of this study is to investigate the impact of corporate social responsibility on firm performance using a longitudinal design in small and medium-sized enterprises (SMEs). The reported study was conducted in a Sub-Saharan African developing country, Zambia. Data were collected from 153 entrepreneurs in two surveys and changes in CSR and firm performance measures were analysed over a 12-month period using SmartPLS structural equation modelling. The findings show that the relationship between CSR and financial performance is significant. Further, the association between CSR and the two measures of firm performance (corporate reputation and employee commitment) was only partially significant over time. We discuss the relevance of these results for entrepreneurs, researchers and policy makers in understanding the outcomes of sustainability practices in SMEs in developing countries, especially in Sub-Saharan Africa.
\end{abstract}

Keywords: CSR; firm performance; longitudinal design; SMEs; developing country; Africa; Zambia

\section{Introduction}

The past couple of decades have seen a growing interest in Corporate Social Responsibility (CSR) research in both commerce and academia. One line of enquiry concerned the outcomes of CSR [1], often exploring the association between CSR and firm performance (e.g., [2-5]). However, results have been mixed with some showing that there is no correlation between CSR and firm performance while other studies establish a positive association, and still others indicate a negative association [4]. These mixed results warrant further research.

It has been observed that a substantial number of studies on the link between CSR and firm performance have focused almost entirely on developed countries [4] and large firms [2]. Small- and medium-sized enterprises (SMEs) have received less attention in this area. Thus, the most obvious gap in the extant literature pertains to the limited number of studies on the link between CSR and firm performance from developing countries' perspectives [6,7]. Kechiche and Soparnot [8] called for the investigation of the links between responsible management for SMEs and financial performance in developing countries. Additionally, those that have examined the link between CSR and firm performance have used cross sectional study designs (e.g., [2,5]), and there are few longitudinal studies examining this association, making it impossible to establish the presence or absence of a causal effect. This may account for variance in the reported results [9]. To the best of our knowledge, there are no peer-reviewed studies that longitudinally examine the association between CSR and firm performance that have been undertaken in a Sub-Saharan African country. The longitudinal approach could help clarify the casual structure of the relationships between CSR and firm performance $[9,10]$.

This study re-examines the link between CSR and firm performance using a longitudinal analysis in Zambia, an under-researched developing Sub-Saharan African country. Zambia is chosen 
for this study because of limited research in sustainable entrepreneurship studies in developing countries [11,12], especially in Sub-Saharan African countries [13-15]. Additionally, a sample from Zambia could be helpful in understanding CSR outcomes in a Sub-Saharan African context. We focus on SMEs because they have received less attention in the study of the link between CSR and firm performance. Studies on CSR in Zambia have mainly concentrated on mining companies but not SMEs, and have not linked CSR to firm performance. To achieve the aim of this study, the following research question is asked: What is the impact of CSR on firm performance in SMEs in Zambia over time? This study is important to entrepreneurs, policy makers and researchers that want to understand the specific CSR practices that impact firm performance and business improvement in SMEs. In addition, the study adds a different aspect to the limited literature on the relationship between CSR and firm performance in Sub-Saharan Africa.

This paper proceeds as follows. The next section first reviews existing works on CSR in SMEs as well as CSR in developing countries' perspectives. Afterwards, we present literature on the CSR-firm performance link, and then we develop the hypotheses to be tested in the study. Thereafter, we explain research methodology, data collection methods, measures used in the study, followed by presentation of results. We conclude the paper by discussing findings, making conclusions, and highlighting future areas of research.

\section{Literature Review and Hypothesis Development}

This section presents the existing literature on CSR by SMEs. It first defines CSR, followed by a review of the characteristics of SMEs. Then, it considers studies on CSR in developing countries perspectives with a particular focus on Sub-Saharan Africa. In the end of the section, we derive the hypothesis to be tested.

\subsection{CSR in SMES}

There has been an increase in CSR studies (e.g., [16-20]). Despite the increase in research on CSR, there is still no generally agreed definition of CSR [21], as a result there is an ambiguous use of the terminology [22]. Fischer [22] and Vo [7] explain that the ambiguity is due to the fact that CSR has been studied in various academic fields. Nevertheless, the Commission of the European Communities (2001), as cited in Dahlsrud [23] (p. 7), defines CSR as "the concept whereby companies integrate their social and environmental concerns in their business operations and in their interaction with their stakeholder on a voluntary basis". This paper uses this definition because it provides a clear conceptualisation of CSR and it has been commonly used by a variety of scholars (e.g., [24]). Further, in addition to identifying the company's obligation toward the social and environmental issues, the definition incorporates three other dimensions of CSR: economic, stakeholders and voluntariness.

Considering the characteristics of SMEs is important in comprehending how CSR is practiced in SMEs. The key difference between large firms and SMEs is that, in the latter, in general, management lies with the owners as opposed to large firms [7,25]. SMEs are located and operate in their local society, thus maintain a close relationship with a number of stakeholders [26]. These characteristics aid SMEs to adopt CSR practices, as most of the decisions are made by the owners of SMEs. Entrepreneurs managing SMEs make decisions, initiate and implement CSR activities $[27,28]$, which in turn contribute to the competitiveness and growth of the firm $[29,30]$. Furthermore, the focus of CSR practices in SMEs is often with the immediate stakeholders, employees, followed by the community, and the least practiced aspect of CSR is environment related [31,32].

Over the years, there has been an increase in CSR in SMEs (e.g., $[13,27])$. Nevertheless, several studies on CSR in SMEs have concentrated on five major areas: the definitions of CSR by SMEs, characteristics of SMEs, motivations of CSR in SMEs, barriers to CSR studies in SMEs, and CSR activities in SMEs [7,8]. Masurel [2] further observed that there have been very few empirical studies on CSR outcomes or impacts of CSR in SMEs. Furthermore, most of the studies on the outcomes of CSR focused on SMEs in developed countries [33]. There has been limited research on SMEs engagement 
in CSR in developing countries $[13,15,33]$. Specifically, few studies investigate the link between CSR practices by SMEs and firm performance from the developing countries' perspectives [6,7]. Thus, there is need for more research on the impact or outcomes of CSR in SMEs.

The mainstream CSR agenda has been criticised because it is largely driven by Western countries' perspectives and has given limited consideration for developing countries' perspectives [14]. While research on CSR in developing countries is limited, within the developing countries' context a large number of the studies focus on Asia and less on Africa [14,34]. Within Africa, the majority of studies focus on South Africa and Nigeria [34]. Therefore, our study focuses on CSR in Zambia, another Sub-Saharan African country.

Most research on CSR in Africa centres on multinational corporations, and the nature and practice of CSR. For example, Demuijnck and Ngnodjom [26] focused on CSR practices in Cameroon. They established four CSR practices: well-being of employees, ethical issues (related to nepotism and tribalism), corruption, and the natural environment. Similarly, Amaeshi et al. [13] and Turyakira, Venter, and Smith [35] reported that CSR practices in SMEs in Sub-Saharan Africa are centred on areas such as the workplace, market place, local community and the natural environment. A number of authors have shown that CSR in Sub-Saharan Africa focus on charity or donations, community involvement, and ethic (e.g., [36-38]). In contrast, Amaeshi et al. [13] found that CSR practice in Africa is beyond charity and in some cases involves institutional works aimed at addressing some institutional gaps in the location where SMEs operate. Overall, the studies above provide insights into the nature and practices of CSR in Sub-Saharan Africa. They however do not investigate the outcome or impact of CSR on the performance of the firm.

Due to the paucity of research on CSR in SMEs in Sub-Saharan Africa, only limited aspects of the CSR-SMEs relationship have been investigated [13]. For example, the link between CSR and firm performance is particularly paltry in Sub-Saharan Africa. This presents an obvious research gap in the relationship between CSR and firm performance in SMEs in Sub-Saharan Africa, as we do not know much about the impact/outcomes of CSR on firm performance in SMEs in this context. Thus, there is a need to further explore the impact or outcomes of CSR in Africa.

Most of the few existing papers we reviewed on CSR in Sub-Saharan Africa were unrelated to our study as they focused mostly on CSR practices only. We however, found one relevant paper by Hilman and Gorondutse [39]. In this paper, the authors examined the association between perceived ethics, social responsibility and firm performance in SMEs in the context of Nigeria. Their findings indicate that perceived social responsibility had a significant effect on firm performance; similarly, perceived ethics positively impacts SMEs performance. Another related study by Turyakira, Venter, and Smith [35] focuses on the relationship between CSR and outcomes (competitiveness). Empirical results indicate that workforce-oriented CSR activities, society-oriented CSR activities, market-oriented CSR activities and regulated oriented CSR activities significantly influence the competitiveness of SMEs in Uganda [35].

These two studies cannot be generalised to the entire continent of Africa with 52 countries because of the huge cross-country differences. Moreover, although developing countries share common features, CSR practices will vary from region to region or even within regions [14] and from country to country $[40,41]$. This is because CSR priorities for action differ from country to country and appear to depend on the perception of the local needs [14]. Besides that, Hilman and Gorondutse [39] used cross-sectional data, making it impossible to study causality. Therefore, in our study, we apply longitudinal analysis to unravel the causal association between CSR and firm performance over time.

\subsection{CSR and Firm Performance in SMEs}

Although CSR in SMEs has gained great attention in the academic and professional fields, the question is whether or not the involvement in CSR activities contributes to firm performance in SMEs in developing countries, especially in the context of Sub-Saharan Africa. Thus far, studies on the relationship between CSR and firm performance show positive, negative, mixed or non-significant 
results [4]. For example, a number of authors found a positive relationship between CSR and firm performance (See $[4,5,42,43]$. In contrast, empirical findings by Boyle, Higgins, and Rhee [44] and Wright and Ferris [45] showed a negative association between CSR and firm performance. Moreover, McWilliams and Siegel [46] found a neutral relationship between CSR and firm performance. Dobre, Stanila, and Brad [16] explain that the fluctuations in results between CSR and firm performance could be related to the context or country of study, industry, different ways of measuring CSR, different methodological approaches or period chosen for analysis. For instance, Ahamed, Almsafir, and Al-Smadi [42] pointed out the need to consider the importance of time frame when investigating the link between CSR and firm performance. This is because even when firms actively engage in CSR, the link between CSR and firm performance may be negative if the country in which the research is conducted had a bad economic period. Therefore, our study applies a longitudinal approach to unravel the causal association between CSR and firm performance because time frame plays an important role when investigating this relationship.

As pointed out earlier, the bulk of studies on the CSR-firm performance link are from developed countries. Thus far, there is limited number of studies on this relationship in developing countries and more especially in Africa. Thus, we cannot generalise the findings from developed countries to developing countries, especially Sub-Saharan African countries without further research. This is because the enterprise structures of SMEs in developed countries often differ from those of developing countries [15]. Besides that, developing countries have different business systems from developed countries. In particular, Sub-Saharan African countries have different business systems, managerial characteristics and institutional environments. For instance, the social and economic crises are mostly felt in developing countries because they are fast expanding economies [34]. Further, in Sub-Saharan Africa, there are greater poverty and more wars, health problems, corruption, misguided aid, social and environment challenges [26,47,48]. Consequently, there is need for more research on the link between CSR and firm performance in this context. In particular, Jamali et al. [15] and Amaeshi et al. [13] called for further studies on the effects/outcomes of CSR in SMEs in developing countries especially Sub-Saharan African countries. This study aims to respond to these calls.

\subsection{Corporate Social Responsibility Studies in Zambia}

A few studies that have previously been conducted on CSR practices in Zambia focus mainly on mining companies (see [37,49-52]). These studies show that the most common CSR activity in Zambia is community involvement. For example, Lungu and Shikwe [37] observed that CSR in Zambia is more social and philanthropic in nature and CSR is viewed as a way of supporting the local community. Similarly, Mayondi [52] reported that CSR in mining firms is mostly focused on community development activities such as building of schools, roads, providing jobs and offering micro-credit loan to people in the local community. There is however one study that focuses on sustainable opportunity identification (opportunities to engage in sustainable behaviour such as CSR) by SMEs in Zambia [53] and another study on CSR motivations in Zambian SMEs [20]. Choongo et al. [53] established that altruism towards others was the main reason why entrepreneurs identify sustainable opportunities. The nature of sustainable opportunities investigated in this study included opportunities related to the social environment (e.g., care for employees, supporting community activities) and natural environment (e.g., recycling, water and energy saving) [54]. Furthermore, Choongo et al. [20] reported that internal motivations (financial motivation and moral and ethical motivation) are the reasons why SMEs adopt community-CSR and environmental-CSR practices in Zambia. In addition, the identification of sustainable opportunities also positively influences the adoption of community-CSR practices. External motivation appears to play no role at all for any form of CSR engagements. However, these two studies did not consider the impact of CSR activities on firm performance.

Prior to 1991, the mining companies in Zambia were owned by a state company called the Zambia Consolidated Copper Mines (ZCCM) Limited and CSR mostly involved philanthropic contributions to communities. ZCCM provided funds for social services such as free health facilities, nappies for the 
newly born babies, recreation activities, free water and electricity for the local community. In addition, education was free for children of employees and other social services such as transport, housing, funeral and burial arrangements including food were heavily subsidised for employees of ZCCM. ZCCM built infrastructure for the local communities such as schools, roads, hospitals, recreation facilities and provided maintenance of the infrastructure, collection of garbage, support of sports and social clubs $[49,50]$. However, there are no studies on the link between CSR and firm performance in SMEs in Zambia. Hence, we do not know whether or not the involvement in CSR activities positively impacts firm performance in Zambia. Thus, this study makes a contribution to the literature on the CSR-firm performance link outside developed countries by investigating the impact of the CSR on firm performance in SMEs in Zambia.

\subsection{Hypotheses Development}

To examine the association between CSR and firm performance, we develop three main explanatory hypotheses. We argue that the involvement in CSR activities has an effect on three different indicators of firm performance: financial performance, firm reputation, and employee commitment.

\subsubsection{Financial Performance}

The first effect of CSR that is taken into account in this study is financial performance. While some studies also show negative or neutral effects, overall, extant literature postulates that CSR impacts firm performance positively. Pan, Sha, Zhang, and Ke [18] observed that employee responsibility and environmental responsibility have significant positive relationships with corporate financial performance. Lee, Herold, and Yu [55] suggested that SMEs are motivated to pursue CSR activities when they perceive a business benefit and value for the company. Further, SMEs engage in community CSR when they perceive benefits such as better business and improved customer loyalty. SMEs also get involved in community responsibility because it results in profitability and growth of the business [56]. CSR outcomes include better relations between the communities and the firm as well as improved firm image. Consequently, this leads to better financial performance in the long term because clients will buy products and services from these firms. Environmental responsibility can also result in better financial performance in the form of cost reduction (waste recycling, reduction in energy and water consumption) [57]. Care for the environment can also result in SMEs to win more contracts with clients that are environmentally conscious which, in turn, can lead to better financial performance of the firm in the long term. It is therefore reasonable to suggest that firms which get involved in community and environmental responsibility can attain improved firm performance in the long term while firms that are unwilling to get involved in CSR perform less well. This leads to the following research hypothesis.

Hypothesis (H1). The engagement in social and environmental responsibility is positively associated with financial performance in SMEs over time.

Hypothesis (H1a). The engagement in social responsibility is positively associated with financial performance in SMEs over time.

Hypothesis (H1b). The engagement in environmental responsibility is positively associated with financial performance in SMEs over time.

\subsubsection{Corporate Reputation}

The second effect of CSR that is taken into account in this study is the firm's reputation. Barnett, Jermier, and Lafferty [58] (p. 34) defined corporate reputation as: "Observers' collective judgments of a corporation based on the assessment of the financial, social, and environmental impacts attributed to the corporation over time." Corporate reputation is also understood as an important intangible resource which can be enhanced or destroyed by the firms' decision to or not to engage in CSR activities and disclosures (Branco and Rodrigues [59] p. 111). Although the firm's reputation is intangible, it aids 
to build sales, and attracts business partners and capital, while aiding the firm to recruit and retain employees and contributes to a company's competitive advantage [60,61]. Entrepreneurs and managers in SMEs expect improved company reputation when they engage in CSR. For example, Turban and Greening [62] established that involvement in CSR activities contributes to a better reputation of the firm in the society, thereby creating a competitive advantage. Enhanced reputation eventually leads to improved firm performance in the long run [63].

The link between CSR and corporate reputation in SMEs is not as straight forward as in large firms. Compared to a large firm, SMEs visibility to the media and the public is more difficult [64]. Entrepreneurs in SMEs prefer not to report or publish their CSR activities [65]. Furthermore, it can be argued that CSR activities in SMEs are informal, ad hoc, usually not reported, and lack visibility; as a result CSR may not have an impact on corporate reputation. However, Fraj-Andrés et al. [64] suggested that CSR activities in SMEs contribute to building a better image and strong marketing position which creates a competitive advantage [66]. In addition, Munasinghe and Malkumari [67] pointed out that SMEs are motivated to engage in CSR activities to improve the firm's reputation, employee motivation and economic performance. Therefore, despite the different characteristics between SMEs and large firms, it is possible that SMEs' involvement in CSR can lead to improved corporate reputation and eventually better firm performance over time. This is because entrepreneurs make decisions based on the fact that CSR improves company reputation and image and increases sales figures [64]. In so doing, improved reputation provides competitive advantages, which positively impacts on organisation performance in the long run. Based on the arguments above, we propose the following hypotheses.

Hypothesis (H2). The engagement in social and environmental responsibility is positively associated with corporate reputation in SMEs over time.

Hypothesis (H2a). The engagement in social responsibility is positively associated with corporate reputation in SMEs over time.

Hypothesis (H2b). The engagement in environmental responsibility is positively associated with corporate reputation in SMEs over time.

\subsubsection{Employee Commitment}

Employee commitment has been defined "as organisational and task commitment, and is related to personal, job or organisation characteristics" [68] (p. 243). Employee commitment is also referred to as the degree to which employees feel devoted to their organisation and the degree of attachment or loyalty employees feel towards the organisation [69,70]. Vance [71] posited that employee's commitment to their firm gives companies vital competitive gains including greater productivity and lower turnover. Past research demonstrates that the involvement in CSR activities can build a strong bond between employees and the organisation, which consequently lead to better employee commitment and organisational performance over time [72]. Albinger and Freeman [73] and Turban and Greening [62] suggested that organisations involved in CSR attract and retain employees, thereby, reducing hiring and training costs, thus, leading to better organisation performance in the long term. A number of authors established that CSR activities have positive significant effects on employee commitment to the organisation (e.g., [4,72-76]). Firms with a good social responsibility can not only attract better employees, but also increase their morale and retain them [59].

In SMEs, CSR focus on the internal stakeholders especially the employees and the community [27,77]. Masurel [31] found that SMEs invest in environmental responsibilities such as improving the working conditions. He further suggested that there may be a connection to "profit", as improvement of working conditions may result in employees having better motivation and fewer sick leaves, thus increasing their productivity on the long-term. Furthermore, in developing countries, in particular Sub-Saharan African countries, entrepreneurs feel responsible for their employees and people living in their communities [32]. It is therefore possible that SMEs' engagement in social activities such as 
providing training to employees, improving working conditions, sponsoring sports and donations so as to enhance their employee commitment to the firm thereby improving organisation performance on the long run. Turker [76] found that social, employee, and customer CSR were significant predictors of the organisation commitment. Similarity, Ali et al. [72] found a positive relationship between CSR and employee commitment to the firm. Based upon these findings, we therefore hypothesise that.

Hypothesis (H3). The engagement in social and environmental responsibility is positively associated with employee commitment in SMEs over time.

Hypothesis (H3a). The engagement in social responsibility is positively associated with employee commitment in SMEs over time.

Hypothesis (H3b). The engagement in environmental responsibility is positively associated with employee commitment in SMEs over time.

\section{Research Methods}

\subsection{Sample and Data Collection}

The data for this study were collected through a longitudinal survey from SMEs that supply goods and services to the mining industry in Zambia. The first fieldwork was done in 2013, while the second survey was carried out on the same sample 12 months later, in 2014. We label the data collected in the first and second field work as $t_{1}$ and $t_{2}$, respectively. The spacing of the period between the two surveys covers a period of 12 months because performance in firms is usually assessed yearly. It is common practice to carry out longitudinal studies at two data points. For example, Bernhard, Donthus and Kennett [78] carried out a longitudinal study at two data points over a 12-month period. Similarly, Mou and Cohen [79] carried out a longitudinal study at two data points over a 6-7-month period. Furthermore, a longer time-period in the dynamic Zambian context, see comments below, may result in high levels of panel attrition. The main goods sold by the firms in the sample include: (1) hardware and electrical items; (2) manufactured items such as industrial cleaning machines, motors, pipes, and valves; (3) consumables, such as cleaning materials, electrodes, and paints; and (4) services including maintenance and repair of industrial equipment and buildings.

The firms were selected based on the criteria of size: SMEs employing between 10 and 250 employees. The sample was drawn from databases of four large mining firms in Zambia (i.e., Mopani Mine, Lumwana Mine, Konkola Mine, and Kansanshi Mine) and had a population of 1200 registered local SMEs that met the selection criteria. At the start of fieldwork, 350 SMEs were randomly selected from the population for this study. When we tried to contact and administer the questionnaire to potential respondents, we experienced some difficulties as we were unable to contact all respondents because a number of firms had either changed their location or their telephone numbers. Apparently, the databases had not been updated for a long time. For this reason, we relied on convenience sampling for the subsequent fieldwork to increase the number of survey participants. Kriauciunas, Parmigiani, and Rivera-Santos [80] acknowledged the difficulties of data collection in developing countries that arise from unreliable databases. Thus, they recommend that the sampling framework and survey administration techniques should be adapted to the context of study. Thus, our survey administration techniques included e-mailing, face-to-face questioning and dropping and picking up the questionnaire later. Overall, we collected 221 completed questionnaires in 2013. In 2014, only 153 of the 221 firms were willing to participate in the survey and completed the questionnaire. Therefore, our final sample for longitudinal analysis consisted of 153 SMEs.

\subsection{Measures of Variables}

\subsubsection{Dependent Variables}

Firm performance-firm performance comprises the actual output or result of an organisation as measured against its inputs. Firm performance is a complex and multidimensional phenomenon [81]. 
Despite this complexity, a number of authors have operationalised firm performance measures in SMEs in two categories: financial performance and non-financial performance (e.g., [39,82]). Examples of financial performance include return on assets, return on equity [83], profit to revenue ratio, cash flow from operations, profit, return on investment, revenue growth, market share gained [84], productivity [2], effectiveness (i.e., sales growth and range of product or service growth), and efficiency (i.e., productivity and profitability growth) [85]. The other measure of firm performance include price per share [10]. Indicators of non-financial performance measures include corporate image, reputation, quality of human resources, customer base, brand devotion, investment in research and development $[39,86]$. Other non-financial performance measures are new product development, capacity to develop competitive profile, market orientation and development [87]. In this study, we use both financial and non-financial measures. The choice of adopting both measures of firm performance arises because SMEs use both financial and non-financial measures to evaluate their performance [82]. Moreover, previous studies indicate that non-financial measures correlated with objective measures [88].

Three measures of firm performance were used in this study-financial performance, corporate reputation and employee commitment because they capture the full impact of CSR on the firm's overall performance compared to single item measurement [4]. Following [4], financial performance was measured using seven items. Respondents were asked to indicate their perceptions of how each of the seven statements described their financial performance relative to their largest competitors on a 5-point Likert scale, from $1=$ strongly disagree to $5=$ strongly agree. The items include, relative to our largest competitor during last year: "we had a larger market share"; "we were larger in size"; "our profit growth has been substantially better"; "our sales growth has been substantially better" "our return on assets has been substantially better"; "our return on investment has been substantially better"; and, regarding the overall performance during last year, "we performed poorly relative to our largest competitor". The latter item is worded in reverse to help control for response bias [89,90]. We used this scale because it is based on perception of the firm's performance as these SMEs are not consistent in keeping historical financial data and thus "objective" performance would be unreliable $[39,81]$. Questionnaire items of different performance measures are shown in Appendix A.

The second dependent variable in this study is corporate reputation; it was measured using three items adopted from Fombrun, Gardberg, and Sever [91]. The first item related to "our organisation has a good reputation", the second "our organisation is widely acknowledged as a trustworthy organisation" and the third item "our organisation is known to sell high quality products and service". All the items measured on a 5 -point Likert scale, from $1=$ strong disagree to $5=$ strongly agree.

The scale for measuring employee commitment was adopted from Jaworski and Kohli [92] and was also used by [4]. The scale consists of three items and is measured on a 5 point Likert scale, from $1=$ strongly disagree to $5=$ strongly agree. The three items were "Our employees are very committed to the organisation", "The bond between the organisation and its employees is very strong", and "Our employees often go above and beyond their regular responsibilities to ensure the organisation's well-being".

\subsubsection{Independent Variables}

Corporate social responsibility was measured on a 16-item scale adopted from Masurel and Rens [19]. We used this measurement instrument in 2013 and 2014 as it was developed earlier. This scale is relevant for studying CSR in SMEs. Preceding our fieldwork, we pre-tested the questionnaire with four academic experts and two entrepreneurs. After the pre-test, questions were rephrased to make them relevant to the setting of the study. For example, the question "My company periodically performs job evaluation interviews" was changed to "My company sponsors students in schools". This is because the outcomes of the pre-test indicated that the original question was not relevant to our study setting. Instead, most entrepreneurs pay for schools fee for students who are orphans or underpriviledged in the local community. The items we used to measure CSR are listed in Appendix A. 


\subsubsection{Control Variables}

We controlled for four variables that might affect the relationship between CSR and firm performance. Moore [93] found that firm age and firm size significantly impact the effects of CSR on firm performance. The other two variables are entrepreneurs age and gender. Firm size was measured as the natural logarithm of the number of employees. Firm age was measured as the natural logarithm of the number of years the business has been in existence based on the second wave of data collection; i.e., 2014. For both firm size and firm age, the natural logarithm was used to avoid skewed distributions [94,95]. We controlled for the entrepreneur's age because older people perceive CSR negatively [96] while young people are more probable to change their CSR perceptions [97]. Gender was included because it affects firm performance [98].

\subsection{Data Analysis and Results}

In this section, we analyse the data and present the results of the study using a longitudinal approach based on the data collected at both times or waves, that is data collected in the first fieldwork $\left(t_{1}\right)$ and data collected in the second fieldwork $\left(t_{2}\right)$ to enable us conclude if CSR affects firm performance over time. We used SmartPLS version 3.2.3 to analyse the data (Ringle, Wende, and Becker [99]). Before testing the hypotheses, we first examine the psychometric properties of the scales described in Section 3.2 by assessing convergent validity, discriminant validity, and reliability of the SmartPLS measurement model.

\subsubsection{Convergent Validity}

The items used to measure corporate reputation, employee commitment, environmental-CSR, financial performance and Social-CSR are listed in Table 1 together with the results of SmartPLS confirmatory factor analysis (CFA), reliability test, and Average Variance Explained (AVE). The loadings and AVE for all items exceeded the 0.5 acceptable threshold, thus convergent validity is confirmed (Henseler, Ringle, and Sinkovics [100]). The composite reliability among all the five latent variables exceeded the threshold of 0.70 suggested by [101]. This demonstrates high level of reliability for all scales in the analysis.

Table 1. Outcomes of the Measurement Model.

\begin{tabular}{ccccc}
\hline Construct & Items & Loadings & Composite Reliability & AVE \\
\hline Corporate Reputation & CopRep1 & 0.837 & 0.913 & 0.777 \\
& CopRep2 & 0.902 & & \\
& CopRep3 & 0.905 & 0.870 & \\
\hline Employee Commitment & EmpCom1 & 0.891 & & 0.527 \\
& EmpCom2 & 0.890 & 0.869 & \\
& EmpCom3 & 0.702 & & \\
\hline Environmental-CSR & EnvCSR1 & 0.741 & & \\
& EnvCSR2 & 0.793 & & \\
& EnvCSR3 & 0.717 & & \\
& EnvCSR4 & 0.750 & & \\
& EnvCSR5 & 0.676 & & \\
& EnvCSR7 & 0.669 & & \\
\hline Financial Performance & FP1 & 0.761 & & \\
& FP2 & 0.768 & & \\
& FP3 & 0.809 & & \\
& FP4 & 0.782 & & \\
& FP5 & 0.780 & & \\
& FP6 & 0.737 & & \\
& SocCSR1 & 0.826 & & \\
& SocCSR2 & 0.800 & & \\
& SocCSR6 & 0.515 & & \\
\hline
\end{tabular}

Note: EnvCSR6, EnvCSR8, F7, SocCSR3, SocCSR4, SocCSR5, SocCSR7, and SocCSR8 were deleted because they had low factor loading $(>0.5)$. 


\subsubsection{Discriminant Validity}

Discriminant validity shows the extent to which one construct is distinct from another construct [101]. To determine the discriminant validity of the construct's used in this research, we followed the criteria suggested by Fornell and Larker [102]. They suggested that the value of the square root of the AVE for each construct should exceed that of correlations between constructs. As can be seen in Table 2, the square root values of the AVE for each construct are higher in comparison with the AVEs in Table 1. This outcome confirms that discriminant validity is present.

Table 2. Discriminant Validity.

\begin{tabular}{ccccccc}
\hline & Construct & $\mathbf{1}$ & $\mathbf{2}$ & $\mathbf{3}$ & $\mathbf{4}$ & $\mathbf{5}$ \\
\hline 1 & Corporate Reputation & $\mathbf{0 . 8 8 2}$ & & & & \\
2 & Employee Commitment & 0.394 & $\mathbf{0 . 8 3 3}$ & & & \\
3 & Environmental-CSR & 0.319 & 0.304 & $\mathbf{0 . 7 2 6}$ & & \\
4 & Financial Performance & 0.218 & 0.246 & 0.391 & $\mathbf{0 . 7 7 3}$ & \\
5 & Social-CSR & 0.239 & 0.255 & 0.336 & 0.364 & $\mathbf{0 . 7 2 8}$ \\
\hline
\end{tabular}

\subsubsection{Measurement Invariance Assessment}

The analysis of measurement invariance is necessary in longitudinal studies (Vandenberg and Lance [103] and before undertaking multigroup analyses in PLS-SEM (Hernandez-Perlines [104]; Hensler, Ringle, and Sarstedt [105]). In this study, we employed Hensler, Ringle, and Sarstedt's [105] three step procedure to assess the measurement invariance of composite models (MICOM) when using SmartPLS. The three steps involve: (1) configural invariance; (2) compositional invariance; and (3) the equality of composition mean values and variances. Step 1 (configural invariance) does not involve any statistical test, instead, it requires and inspection of the models set-up. In this study, the measurement and structural model for the two groups of data (data collected in the first fieldwork $\left(t_{1}\right)$ and data collected in the second fieldwork $\left(t_{2}\right)$ are identical, thus configural invariance is established. Step 2 (compositional invariance) involves carrying out permutation test. If the permutation test reveals that the correlation $c$ values are not significantly different from one, then composition invariance is established. In this study, 5000 permutations were carried out. Table 3 shows that the lowest correlation value of social-CSR is 0.989 and is very close to one and none of the $c$ values are significantly different from one. Thus, compositional invariance is established for all composite in the CSR-Firm performance model. In Step 3, we assessed the composites equality of mean values and variances. The assessment show that the mean values and variances of composites do not significantly differ. Thus, the equality of compositional mean values and variance are established. In conclusion, measurement invariance is established for all the three steps of the MICOM procedure of the CSR-Firm performance model. Thus, full measurement invariance is supported for the two groups of data (data collected in the first fieldwork $\left(t_{1}\right)$ and data collected in the second fieldwork $\left(t_{2}\right)$.

Table 3. MICOM results of CSR and Firm Performance Relationship.

\begin{tabular}{cccc}
\hline Composite & c-Value & 95\% Confidence Interval & Compositional Invariance? \\
\hline Corporate Reputation & 0.9992 & {$[1.0000 ; 1.0000]$} & Yes \\
Employee Commitment & 0.9977 & {$[0.9999 ; 1.0000]$} & Yes \\
Environmental-CSR & 0.9907 & {$[0.9988 ; 1.0000]$} & Yes \\
Financial Performance & 0.9926 & {$[0.9995 ; 1.0000]$} & Yes \\
Social-CSR & 0.9771 & {$[0.9989 ; 1.0000]$} & Yes \\
\hline Composite Difference of the composites' mean value & $95 \%$ confidence interval & Equal mean values? \\
\hline Corporate Reputation & -0.001 & {$[-0.007 ; 0.007]$} & Yes \\
Employee Commitment & 0.001 & {$[0.001 ;-0.006]$} & Yes \\
Environmental-CSR & -0.001 & {$[-0.001 ;-0.008]$} & Yes \\
Financial Performance & 0.000 & {$[-0.006 ; 0.008]$} & Yes \\
Social-CSR & 0.002 & {$[-0.004 ; 0.008]$} & \\
\hline
\end{tabular}


Table 3. Cont.

\begin{tabular}{cccc}
\hline Composite & c-Value & 95\% Confidence Interval & Compositional Invariance? \\
\hline Composite Difference of the composites' & variance ratio $(=0)$ & $95 \%$ confidence interval & Equal variance? \\
\hline Corporate Reputation & 0.001 & {$[-0.011 ; 0.012]$} & Yes \\
Employee Commitment & -0.003 & {$[0.001 ; 0.011]$} & Yes \\
Environmental-CSR & -0.004 & {$[-0.017 ; 0.009]$} & Yes \\
Financial Performance & 0.000 & {$[-0.010 ; 0.012]$} & Yes \\
Social-CSR & -0.001 & {$[-0.019 ; 0.007]$} & Yes \\
\hline
\end{tabular}

\subsubsection{Model Fit}

SmartPLS measures model fitness by the Goodness of Fit (GOF) and the standard square residual (SRMR). GOF is defined as the geometric mean of the average AVE and average $R^{2}$ (for dependent variables).

$$
\mathrm{GOF}=\sqrt{ } \mathrm{AVE} \times \sqrt{ } \mathrm{R}^{2}
$$

Akter et al. [106] suggest that the values of GOF of 0.1 are small, 0.25 are medium and 0.36 are large. Using the formula above, we obtained a GOF of 0.32 . The standardized root mean square residual (SRMR) value for this study is 0.000 . A cut off point of 0.10 indicated the model has a good fit (Garson [107]).

\subsubsection{Hypothesis Testing}

To examine the impact of CSR on firm performance over time, a longitudinal analysis was conducted using data collected in 2013 and 2014. We used data on changes in CSR and changes in the three indicators of performance (i.e., $\left.t_{2}-t_{1}\right)$. Each of the three main hypotheses $(\mathrm{H} 1, \mathrm{H} 2$, and $\mathrm{H} 3)$ consists of two sub-hypotheses: $\mathrm{H} 1 \mathrm{a}$ and $\mathrm{H} 1 \mathrm{~b} ; \mathrm{H} 2 \mathrm{a}$ and $\mathrm{H} 2 \mathrm{~b}$; and $\mathrm{H} 3 \mathrm{a}$ and $\mathrm{H} 3 \mathrm{~b}$, respectively. Thus, we test the main hypotheses by testing the sub-hypotheses. To test the sub-research hypotheses $\mathrm{H} 1 \mathrm{a}-\mathrm{H} 3 \mathrm{~b}$, we ran the PLS Algorithm and the bootstrapping procedure with 500 sub-samples in SmartPLS 3.2.3. The relationships are tested using the path coefficients and the level of significance. We checked for multicollinearity using the VIF in SPSS. The VIF scores ranged from 1.026 to 1.121, indicating that multicollinearity does not play a role [101]. Figure 1 and Table 4 show the results of the SEM including the paths estimates and the $p$-values. Even though we controlled for age, gender, firm size, and firm age, the control variables were omitted in the final model because they were insignificant.

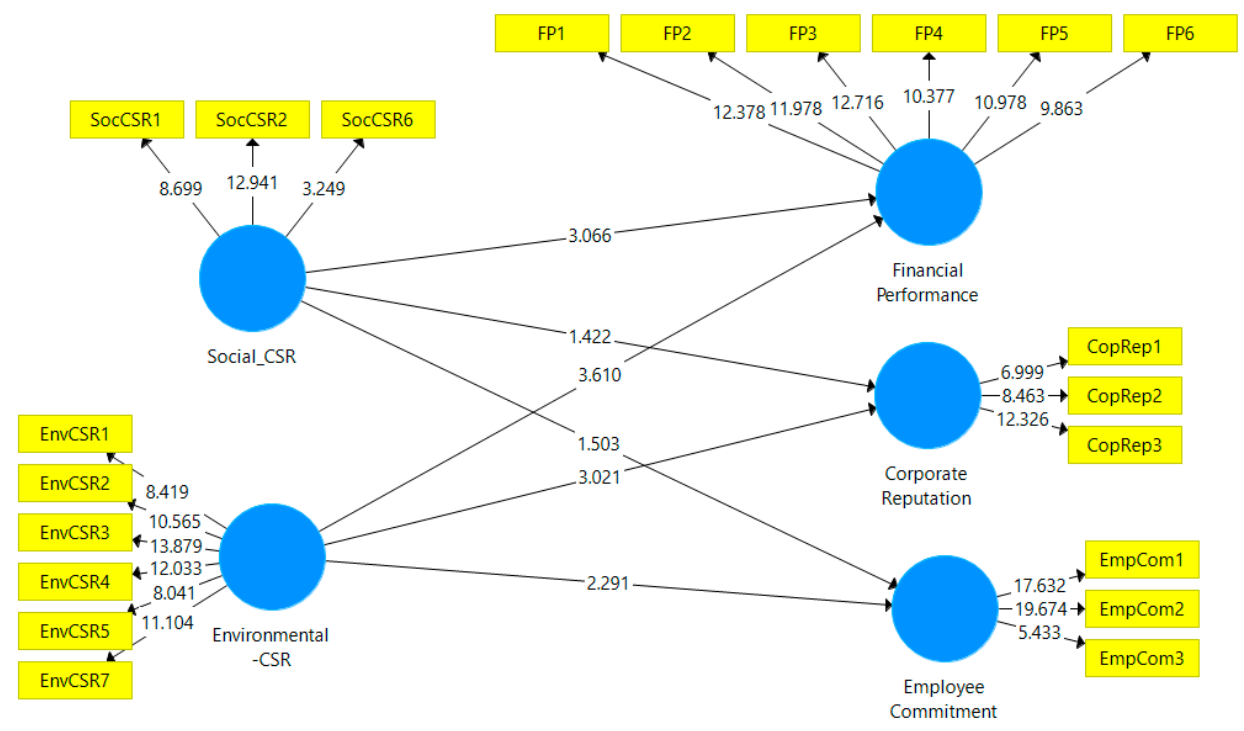

Figure 1. Structural and Measurement Model. 
Table 4. Results of the Structural Equation Model and Hypothesis testing.

\begin{tabular}{|c|c|c|c|c|c|c|c|}
\hline Hypothesis & Relationship & $\begin{array}{c}\text { Path } \\
\text { Coefficient }\end{array}$ & $\begin{array}{c}\text { Sample } \\
\text { Mean }\end{array}$ & $\begin{array}{l}\text { Standard } \\
\text { Deviation }\end{array}$ & T Statistics & $p$ Values & Decision \\
\hline $\mathrm{H} 2 \mathrm{~b}$ & $\begin{array}{l}\text { Environmental-CSR } \rightarrow \\
\text { Corporate Reputation }\end{array}$ & 0.269 & 0.286 & 0.089 & 3.021 & $0.003^{* *}$ & Supported \\
\hline $\mathrm{H} 3 \mathrm{~b}$ & $\begin{array}{l}\text { Environmental-CSR } \rightarrow \\
\text { Employee Commitment }\end{array}$ & 0.246 & 0.269 & 0.108 & 2.291 & $0.022 * *$ & Supported \\
\hline $\mathrm{H} 1 \mathrm{~b}$ & $\begin{array}{l}\text { Environmental-CSR } \rightarrow \\
\text { Financial Performance }\end{array}$ & 0.303 & 0.323 & 0.084 & 3.610 & $0.000^{* * *}$ & Supported \\
\hline $\mathrm{H} 2 \mathrm{a}$ & $\begin{array}{c}\text { Social-CSR } \rightarrow \\
\text { Corporate Reputation }\end{array}$ & 0.149 & 0.147 & 0.104 & 1.422 & 0.156 & Rejected \\
\hline $\mathrm{H} 3 \mathrm{a}$ & $\begin{array}{c}\text { Social-CSR } \rightarrow \\
\text { Employee Commitment }\end{array}$ & 0.172 & 0.164 & 0.114 & 1.503 & 0.133 & Rejected \\
\hline $\mathrm{H} 1 \mathrm{a}$ & $\begin{array}{c}\text { Social-CSR } \rightarrow \text { Financial } \\
\text { Performance }\end{array}$ & 0.262 & 0.261 & 0.085 & 3.066 & $0.002 * *$ & Supported \\
\hline
\end{tabular}

The highest coefficient value from the original sample is 0.303 for Environmental-CSR $\rightarrow$ Financial Performance, followed by Environmental-CSR $\rightarrow$ Corporate Reputation (0.269), while Social-CSR $\rightarrow$ Social-CSR $\rightarrow$ corporate reputation and Employee Commitment have the least values of 0.149 and 0.172 , respectively.

As can be seen in Figure 1 and Table 4, there is a positive relationship between social-CSR and financial performance as the path coefficient value was found to be $\beta=0.262(p<0.05)$. The effect of environmental-CSR on financial performance is significant with a path coefficient value of $\beta=0.303$ $(p<0.05)$. Thus, $\mathrm{H} 1$ is fully supported. $\mathrm{H} 2$ posited that engagement in social and environmental responsibility is positively associated with corporate reputation. Test results of $\mathrm{H} 2 \mathrm{a}$ indicate that the relationship between social-CSR and corporate reputation is not supported as the path coefficient value was found to be $\beta=0.149(p>0.10)$, while $\mathrm{H} 2 \mathrm{~b}$ results indicate that the relationship between environmental-CSR and corporate reputation is supported as the path coefficient value was found to be $\beta=0.269(p<0.05)$. Therefore, $\mathrm{H} 2$ is partially supported. Hypothesis 3 posited that the engagement in social and environmental responsibility is positively associated with employee commitment. H3a indicate that the relationship between social-CSR and employee commitment is not supported as the path coefficient value was found to be $\beta=0.172(p>0.10)$, while H3b results indicate that the relationship between environmental-CSR and employee commitment is supported with a path coefficient value of $\beta=0.246(p<0.05)$. Thus, $\mathrm{H} 3$ is partially supported. The results of the $\mathrm{R}^{2}$ were 0.21 , 0.12 , and 0.12 for financial performance, corporate reputation and employee commitment, respectively.

\section{Discussion}

The present study was designed to examine the impact of CSR on firm performance in Zambian SMEs using a longitudinal analysis. Data were collected at two time-points, 12 months apart. Thus, longitudinal analysis of the association between CSR and the three indicators of firm performance (financial performance, corporate reputation and employee commitment) were conducted. The longitudinal analysis results reported in this study show that the two dimensions of CSR (social and environmental) significantly impact financial performance. However, the association between the two dimensions of CSR and the other two measures of firm performance (corporate reputation and employee commitment) only turned out to be partially significant.

We found that the relationship between CSR and financial performance is significant and fully supported. The positive effect of CSR on financial performance is consistent with many studies conducted in Western, Asian, and other countries (e.g., [4,16-18,43]). Additionally, in the context of Zambia, Choongo et al. [20] established that SMEs are motivated to engage in CSR for financial benefits. It is therefore expected that the involvement in CSR activities such as reduction in energy and water 
usage translates in cost savings which ultimately improve firm performance. These findings imply that in non-Western contexts, CSR also positively impacts firm performance.

The relationship between CSR and corporate reputation is only partially accepted. Perhaps corporate reputation has less impact on SMEs than on large corporates. Fraj-Andrés et al. [64] explained that SMEs visibility to the public and media is more difficult and SMEs do not normally publicise or report their CSR activities [65]. Hence, CSR may not have a great impact on corporate reputation even though other authors, such as Turban and Greening [62], suggest that CSR activities in SMEs contribute to building a better image and strong marketing position which consequently leads to a competitive advantage.

The result of the association between CSR and employee commitment is also only partially accepted. This is a surprising result because CSR in Sub-Saharan Africa emphasises community ties and entrepreneurs feel responsible for the well-being of the community and employees including their family members $[26,36,77]$. Strong community ties enhances the bond between the firm and its employyes. The care for the community and employees and their family members may lead to increased employee commitment thereby improving employee productivity which may ultimately result in improved performance in an organisation in the long run [72]. A possible explanation for this result may be that, attempts to improve firm performance may require spending money on buying assets, marketing the products, hiring employees, training and developing employees. This may negatively affect employee commitment to the firm. Entrepreneurs managing SMEs can invest in CSR activities such as training and development that raise employee commitment to the firm, thereby improving the performance of the firm over time. If employees are very committed to the organisation, it will lead to employee retention and less costs in hiring new employees, thereby improving the performance of the firm over time.

\section{Limitations}

This research has several limitations. First, the study's sample was drawn from one sector (trading and service), which might limit the generalisability of these findings to other sectors. Future studies should verify these findings across sectors. Second, we used perceptual measures of financial performance due to lack of objective measures in SMEs, even though subjective/perceptual measures correlate with objective measures [88]. Future researchers should endeavour to use objective measures of firm performance. Third, we did not investigate what drives changes in CSR and employee commitment over time. Future researchers can ask questions such as "what drives changes in the CSR and firm performance link overtime and when might CSR impact firm performance?" Finally, we collected two waves of data, 12 months apart. Future studies should consider collecting three or more waves of data to examine the causal change in the link between CSR and firm performance. These results are helpful to entrepreneurs, researchers and policy makers in understanding the outcomes of CSR in SMEs in developing countries, especially in Sub-Saharan Africa.

\section{Conclusions}

In sum, the most significant finding from our longitudinal analysis is that there is a significant effect of CSR on financial performance over a 12-month period. Furthermore, even though our study shows that there are limited effects of changes in the two dimensions of CSR on corporate reputation as well as on employee commitment over time, our evidence adds to the existing literature in entrepreneurship and small business in non-Western contexts by showing that there is a positive effect of changes in CSR on firm performance in the long run. The results of this study carried out in a Sub-Saharan African country are similar to previous empirical evidence from Western and Asian countries showing that CSR activities positively impact on firm performance. In comparison with previous studies, our results support the view that the involvement in CSR has the potential to lead to improved firm performance. We can therefore conclude that by applying a longitudinal analysis on the effects of CSR on firm performance, our empirical analysis helps to clarify the causal effect of 
the relationship between CSR and firm performance. This is because the use of longitudinal analysis overcomes the limitations and biases that may arise from cross sectional analysis. This study has implication for entrepreneurs, researchers and policy makers in that they should exercise patience in evaluating the outcomes of the CSR activities in SMEs in Sub-Saharan African developing countries. It is clear from our longitudinal analysis that CSR activities can result in increased firm performance over a period of time.

Acknowledgments: This study is partly funded by NUFFIC-NICHE (as part of the HEART Project). The author appreciate Elco Van Burg, Enno Masurel (Vrije Universiteit, Amsterdam), Leo J. Paas (Massey University, New Zealand) and John Lungu (Copperbelt University, Zambia) for the advice provided in the design and writing of the research.

Conflicts of Interest: The authors declare no conflict of interest.

\section{Appendix A}

Table A1. Questionnaire Items.

\begin{tabular}{|c|c|c|}
\hline Construct & Label & Items \\
\hline \multirow[t]{9}{*}{ Financial Performance } & & Relative to our largest competitors, during last year we \\
\hline & FP1 & We had larger market share. \\
\hline & FP2 & We were larger in size. \\
\hline & FP3 & Our profit growth has been substantially better. \\
\hline & FP4 & Our sales growth has been substantially better. \\
\hline & FP5 & Our return on assets has been substantially better. \\
\hline & FP6 & Our return on investment has been substantially better. \\
\hline & & Regarding our overall performance, during last year we \\
\hline & FP7 & Performed poorly relative to competitors \\
\hline \multirow{4}{*}{ Corporate Reputation } & & During last five years \\
\hline & CorpRep1 & Our organisation has a good reputation. \\
\hline & CorpRep2 & Our organisation is widely acknowledged as a trustworthy organisation. \\
\hline & CorpRep3 & Our organisation is known to sell high quality products and service. \\
\hline \multirow[t]{4}{*}{ Employee Commitment } & & During last five years \\
\hline & EmpCom1 & Our employees are very committed to the organisation. \\
\hline & EmpCom2 & The bond between the organisation and its employees is very strong. \\
\hline & EmpCom3 & $\begin{array}{l}\text { Our employees often go above and beyond their regular responsibilities to } \\
\text { ensure the organisation's well-being. }\end{array}$ \\
\hline \multirow[t]{8}{*}{ Social-CSR } & SocCSR1 & My company ensures workplace health and safety \\
\hline & SocCSR2 & My company implements training and development programs for employees \\
\hline & SocCSR3 & My company periodically tests employee satisfaction \\
\hline & SocCSR4 & My company human resource policy is partially aimed at workplace diversity \\
\hline & SocCSR5 & My company sponsors students in schools \\
\hline & SocCSR6 & My company offers industrial attachments (internships) to students \\
\hline & SocCSR7 & My company uses a formal customer complaints register for clients \\
\hline & SocCSR8 & My company is active within an organisation with a social purpose \\
\hline \multirow[t]{8}{*}{ Environmental-CSR } & EnvCSR1 & My company saves energy beyond legal requirements \\
\hline & EnvCSR2 & My company saves water beyond legal requirements \\
\hline & EnvCSR3 & My company voluntarily does recycling and/or re-use \\
\hline & EnvCSR4 & My company takes action in order to reduce waste \\
\hline & EnvCSR5 & My company purchases environmentally friendly products \\
\hline & EnvCSR6 & My company is a member of an environmental organisation \\
\hline & EnvCSR7 & $\begin{array}{l}\text { My company is well equipped in order to improve the sustainability/CSR of } \\
\text { my clients }\end{array}$ \\
\hline & EnvCSR8 & My company suggests sustainable solutions to our clients \\
\hline
\end{tabular}

\section{References}

1. Aguinis, H.; Glavas, A. What We Know and Don't Know About Corporate Social Responsibility: A Review and Research Agenda. J. Manag. 2012, 38, 932-968. [CrossRef] 
2. Masurel, E. Social and ecological engagement and economic firm performance: Correlated or not? CSR evidence from SMEs in two Dutch retail sectors. In Proceedings of the Conference of Growing Sustainable Business, Tilburg University, Tilburg, The Netherlands, 17 April 2015.

3. Mishra, S.; Suar, D. Does corporate social responsibility influence firm performance in Indian companies? J. Bus. Ethics 2010, 95, 571-601. [CrossRef]

4. Rettab, B.; Brik, A.B.; Mellahi, K. A Study of Management Perceptions of the Impact of Corporate Social Responsibility on Organisational Performance in Emerging Economies: The Case of Dubai. J. Bus. Ethics 2009, 89, 371-390. [CrossRef]

5. Saeidi, S.P.; Sofian, S.; Saeidi, P.; Saeidi, S.P.; Saaeidi, S.A. How does corporate social responsibility contribute to firm financial performance? The mediating role of competitive advantage, reputation, and customer satisfaction. J. Bus. Res. 2015, 68, 341-350. [CrossRef]

6. Moore, G.; Spence, L. Editorial: Responsibility and small business. J. Bus. Ethics 2006, 67, 219-226. [CrossRef]

7. Vo, L.C. Corporate social responsibility and SMEs: A literature review and agenda for future research. Probl. Perspect. Manag. 2011, 9, 89-97.

8. Kechiche, A.; Soparnot, R. CSR within SMEs: Literature review. Int. Bus. Res. 2012, 5, 97. [CrossRef]

9. Allouche, J.; Laroche, P. A meta-analytical investigation of the relationship between corporate social and financial performance. Rev. Gest. Ressour. Hum. 2005, 57, 18.

10. Orlitzky, M.; Schmidt, F.L.; Rynes, S.L. Corporate social and financial performance: A meta-analysis. Organ. Stud. 2003, 24, 403-441. [CrossRef]

11. Hall, J.K.; Daneke, G.A.; Lenox, M.J. Sustainable Development and Entrepreneurship: Past Contributions and Future Directions. J. Bus. Ventur. 2010, 25, 439-448. [CrossRef]

12. Bruton, G.D.; Ahlstrom, D.; Obloj, K. Entrepreneurship in Emerging Economies: Where Are We Today and Where Should the Research Go in the Future. Entrep. Theory Pract. 2008, 32, 1-14. [CrossRef]

13. Amaeshi, K.; Adegbite, E.; Ogbechie, C.; Idemudia, U.; Kan, K.A.S.; Issa, M.; Anakwue, O.I.J. Corporate Social Responsibility in SMEs: A Shift from Philanthropy to Institutional Works? J. Bus. Ethics 2017, 138, 385-400. [CrossRef]

14. Idemudia, U. Corporate social responsibility and developing countries: Moving the critical CSR research agenda in Africa forward. Progress Dev. Stud. 2011, 11, 1-18. [CrossRef]

15. Jamali, D.; Lund-Thomsen, P.; Jeppesen, S. SMEs and CSR in Developing Countries. Bus. Soc. 2017, 56, 11-22. [CrossRef]

16. Dobre, E.; Stanila, G.O.; Brad, L. The influence of environmental and social performance on financial performance: Evidence from Romania's listed entities. Sustainability 2015, 7, 2513-2553. [CrossRef]

17. Lin, C.-S.; Chang, R.-Y.; Dang, V.T. An integrated model to explain how corporate social responsibility affects corporate financial performance. Sustainability 2015, 7, 8292-8311. [CrossRef]

18. Pan, X.; Sha, J.; Zhang, H.; Ke, W. Relationship between corporate social responsibility and financial performance in the mineral Industry: Evidence from Chinese mineral firms. Sustainability 2014, 6, 4077-4101. [CrossRef]

19. Masurel, E.; Rens, J. How Is CSR-Intensity Related to the Entrepreneur's Motivation to Engage in CSR? Empirical Evidence from Small and Medium-Sized Enterprises in the Dutch Construction Sector. Int. Rev. Entrep. 2015, 13, 333-348.

20. Choongo, P.; van Burg, E.; Masurel, E.; Paas, L.J.; Lungu, J. Corporate Social Responsibility Motivations in Zambian SMEs. Int. Rev. Entrep. 2017, 15, $29-62$.

21. Popa, M.; Salanta, I. Corporate social responsibility versus corporate social irresponsibility. Manag. Mark. 2014, 9, 137.

22. Fischer, F. Sustainability: The Concept of Modern society in Idowu E Schmidpeter (Eds), Corporate Social Responsibility, Sustainability, Ethics and Governance; Springer: Berlin, Germany, 2013.

23. Dahlsrud, A. How Corporate Social Responsibility is Defined: An Analysis of 37 Definitions. Corp. Soc. Responsib. Environ. Manag. 2008, 15, 1-13. [CrossRef]

24. Carroll, A.B.; Shabana, K.M. The business case for corporate social responsibility: A review of concepts, research and practice. Int. J. Manag. Rev. 2010, 12, 85-105. [CrossRef]

25. Spence, L.J.; Rutherfoord, R. Small business and empirical perspectives in business ethics: Editorial. J. Bus. Ethics 2003, 47, 1-5. [CrossRef] 
26. Demuijnck, G.; Ngnodjom, H. Responsibility and Informal CSR in Formal Cameroonian SMEs. J. Bus. Ethics 2013, 112, 653-665. [CrossRef]

27. Jenkins, H. Small Business Champions for Corporate Social Responsibility. J. Bus. Ethics 2006, 67, 241-256. [CrossRef]

28. Williams, S.; Schaefer, A. Small and medium sized enterprises and sustainability: Managers' values and engagement with environmental and climate change issues. Bus. Strategy Environ. 2013, 22, 173-186. [CrossRef]

29. Moore, S.B.; Manring, S.L. Strategy development in small and medium sized enterprises for sustainability and increased value creation. J. Clean. Prod. 2009, 17, 276-282. [CrossRef]

30. Revell, A.; Stokes, D.; Chen, H. Small Business and the Environment: Turning Over the Leaf? Bus. Strategy Environ. 2010, 19, 273-288.

31. Masurel, E. Why SMEs Invest in Environmental Measures: Sustainability Evidence from Small and Medium-Sized Printing Firms. Bus. Strategy Environ. 2007, 16, 190-201. [CrossRef]

32. Spence, M.; Gherib, J.B.B.; Biwole, V.O. Sustainable Entrepreneurship: Is Entrepreneurship will Enough? A North-South Comparison. J. Bus. Ethics 2011, 99, 335-367. [CrossRef]

33. De Oliveira, J.A.P.; Jabbour, C.J.C. Environmental Management, Climate Change, CSR, and Governance in Clusters of Small Firms in Developing Countries Toward an Integrated Analytical Framework. Bus. Soc. 2017, 56, 130-151. [CrossRef]

34. Visser, W.; McIntosh, M.; Middleton, C. Corporate Citizenship in Africa; Greenleaf: Sheffield, UK, 2006.

35. Turyakira, P.; Venter, E.; Smith, E. The impact of corporate social responsibility factors on the the competitiveness of small and medium-sized enterprises. S. Afr. J. Econ. Manag. Sci. 2014, 17, 157-172. [CrossRef]

36. Amaeshi, K.M.; Adi, B.C.; Ogbechie, C.; Amao, O.O. Corporate Social Responsibility in Nigeria: Western Mimicry or Indigenous Influences? J. Corp. Citizensh. 2006, 24, 83-99. [CrossRef]

37. Lungu, J.; Shikwe, A. Corporate Social Responsibility Practices in Small-Scale Mining on the Copperbelt; Mission Press: Ndola, Zambia, 2006.

38. Muthuri, J.N.; Gilbert, V. An Institutional Analysis of Corporate Social Responsibility in Kenya. J. Bus. Ethics 2011, 98, 467-483. [CrossRef]

39. Hilman, H.; Gorondutse, A.H. Relationship between perceived ethics and Trust of Business Social Responsibility (BSR) on performance of SMEs in Nigeria. Middle East J. Sci. Res. 2013, 15, 36-45.

40. World Business Council for Sustainable-Development. Corporate Social Responsibility: Meeting Changing Expectations; World Business Council for Sustainable Development: Geneva, Switzerland, 1999.

41. World Business Council for Sustainable-Development. Corporate Social Responsibility: Making Good Business Sense; World Business Council for Sustainable Development: Geneva, Switzerland, 2000.

42. Ahamed, W.S.W.; Almsafir, M.K.; Al-Smadi, A.W. Does corporate social responsibility lead to improve in firm financial performance? Evidence from malaysia. Int. J. Econ. Financ. 2014, 6, 126.

43. Torugsa, N.A.; O'Donohue, W.; Hecker, R. Capabilities, proactive CSR and financial performance in SMEs: Empirical evidence from an Australian manufacturing industry sector. J. Bus. Ethics 2012, 109, 483-500. [CrossRef]

44. Boyle, E.J.; Higgins, M.M.; Rhee, G.S. Stock Market Reaction to Ethical Initiatives of Defense Contractors: Theory and Evidence. Crit. Perspect. Account. 1997, 8, 541-561. [CrossRef]

45. Wright, P.; Ferris, S.P. Agency Conflict and Corporate Strategy: The Effect of Divestment on Corporate Value. Strateg. Manag. J. 1997, 18, 77-83. [CrossRef]

46. McWilliams, A.; Siegel, D. Corporate social responsibility: A theory of the firm perspective. Acad. Manag. Rev. 2001, 26, 117-127.

47. Dobers, P.; Halme, M. Corporate social responsibility and developing countries. Corp. Soc. Responsib. Environ. Manag. 2009, 16, 237-249. [CrossRef]

48. Spence, L.J.; Painter-Morland, M. Ethics in Small and Medium Sized Enterprises. A Global Commentary; Springer: Dordrecht, The Netherlands, 2010.

49. Fraser, A.; Lungu, J. For Whom The Windfalls? Winners \& Losers in the Privatisation of Zambia's Copper Mines: Printex, Lusaka, Zambia, 2007.

50. Lungu, J.; Kapena, S. South African Mining Companies Corporate Governance Practices in Zambia: The Case of Chibuluma Mine; Southern Africa Resource: Johannesburg, South Africa, 2010; pp. 47-97. 
51. Lungu, J.; Mulenga, C. Corporate Social Responsibility Practices in the Extractive Industry in Zambia; Mission Press: Ndola, Zambia, 2005.

52. Mayondi, W. Mining and Corporate Social Responsibility in Zambia: A Case Study of Barrick Gold Mine. Masters' Thesis, Victoria University of Wellington, Wellington, New Zealand, 2014.

53. Choongo, P.; Van Burg, E.; Paas, L.J.; Masurel, E. Factors Influencing the Identification of Sustainable Opportunities by SMEs: Empirical Evidence from Zambia. Sustainability 2016, 8, 81. [CrossRef]

54. Patzelt, H.; Shepherd, D.A. Recognising Opportunities for Sustainable Development. Entrep. Theory Pract. 2011, 35, 631-652. [CrossRef]

55. Lee, K.-H.; Herold, D.M.; Yu, A.-L. Small and Medium Enterprises and Corporate Social Responsibility Practice: A Swedish Perspective. Corp. Soc. Responsib. Environ. Manag. 2015, 23, 88-99. [CrossRef]

56. Mankelow, G.; Quazi, A. Factors affecting SMEs Motivations for Corporate Social Responsibility, in Australan and New Zeland Marketing Academy. Conf. Track 2007, 5, 2367-2374.

57. Graafland, J.; Mazereeuw-Van der Duijn Schouten, C. Motives for Corporate Social Responsibility. De Econ. 2012, 160, 377-396. [CrossRef]

58. Barnett, M.L.; Jermier, J.M.; Lafferty, B.A. Corporate reputation: The definitional landscape. Corp. Reput. Rev. 2006, 9, 26-38. [CrossRef]

59. Branco, M.C.; Rodrigues, L.L. Corporate social responsibility and resource-based perspectives. J. Bus. Ethics 2006, 69, 111-132. [CrossRef]

60. Nowduri, S. Framework for Sustainability Entrepreneurship for Small and Medium Enterprises (SMEs) in an Emerging Economy. World J. Manag. 2012, 4, 51-66.

61. Pharoah, A. Corporate reputation: The boardroom challenge. Corp. Gov. Int. J. Bus. Soc. 2003, 3, 46-51. [CrossRef]

62. Turban, D.B.; Greening, D.W. Corporate social performance and organizational attractiveness to prospective employees. Acad. Manag. J. 1997, 40, 658-672. [CrossRef]

63. Eberl, M.; Schwaiger, M. Corporate reputation: Disentangling the effects on financial performance. Eur. J. Mark. 2005, 39, 838-854. [CrossRef]

64. Fraj-Andrés, E.; López-Pérez, M.E.; Melero-Polo, I.; Vázquez-Carrasco, R. Company image and corporate social responsibility: Reflecting with SMEs' managers. Mark. Intell. Plan. 2012, 30, 266-280. [CrossRef]

65. Jamali, D.; Zanhour, M.; Keshishian, T. Peculiar strengths and relational attributes of SMEs in the context of CSR. J. Bus. Ethics 2009, 87, 355-377. [CrossRef]

66. Alshammari, M. Corporate Social Responsibility and Firm Performance: The Moderating Role of Reputation and Institutional Investors. Int. J. Bus. Manag. 2015, 10, 15. [CrossRef]

67. Munasinghe, M.; Malkumari, A. Corporate social responsibility in small and medium enterprises (SME) in Sri Lanka. J. Emerg. Trends Econ. Manag. Sci. 2012, 3, 168.

68. Nijhof, W.J.; Jong, M.J.D.; Beukhof, G. Employee commitment in changing organizations: An exploration. J. Eur. Ind. Train. 1998, 22, 243-248. [CrossRef]

69. Akintayo, D. Work-family role conflict and organizational commitment among industrial workers in Nigeria. Int. J. Psychol. Couns. 2010, 2, 1-8.

70. Ongori, H. A review of the literature on employee turnover. Afr. J. Bus. Manag. 2007, 1, 49-54.

71. Vance, R.J. Employee Engagement and Commitment. SHRM Found, 2006. Available online: https:/ / www.shrm.org/foundation/ourwork/initiatives/resources-from-past-initiatives/Documents / Employee\%20Engagement\%20and\%20Commitment.pdf (accessed on 21 September 2016).

72. Ali, I.; Rehman, K.U.; Ali, S.I.; Yousaf, J.; Zia, M. Corporate social responsibility influences, employee commitment and organizational performance. Afr. J. Bus. Manag. 2010, 4, 2796-2801.

73. Albinger, H.S.; Freeman, S.J. Corporate social performance and attractiveness as an employer to different job seeking populations. J. Bus. Ethics 2000, 28, 243-253. [CrossRef]

74. Brammer, S.; Millington, A.; Rayton, B. The contribution of corporate social responsibility to organizational commitment. Int. J. Hum. Resour. Manag. 2007, 18, 1701-1719. [CrossRef]

75. Greening, D.W.; Turban, D.B. Corporate social performance as a competitive advantage in attracting a quality workforce. Bus. Soc. 2000, 39, 254-280. [CrossRef]

76. Turker, D. How corporate social responsibility influences organizational commitment. J. Bus. Ethics 2009, 89, 189-204. [CrossRef] 
77. Vives, A. Social and Environmental Responsibility in Small and Medium Enterprises in Latin America; Inter-American Bank, Sustainable Department: Washington, DC, USA, 2005.

78. Bernhardt, K.L.; Donthu, N.; Kennett, P.A. A longitudinal analysis of satisfaction and profitability. J. Bus. Res. 2000, 47, 161-171. [CrossRef]

79. Mou, J.; Cohen, J.F. A longitudinal Study of Trust and Perceived Usefulness in Consumer Acceptance of an eService: the Case of Online Health Services; PACIS: Langkawi, Malaysia, 2014.

80. Kriauciunas, A.; Parmigiani, A.; Rivera-Santos, M. Leaving our comfort zone: Intergrating established practices with uniques adaptations to conduct survey-based strategy research in nontraditional contexts. Strateg. Manag. J. 2011, 32, 994-1010. [CrossRef]

81. Dess, G.G.; Robinson, R.B. Measuring organizational performance in the absence of objective measures: The case of the privately-held firm and conglomerate business unit. Strateg. Manag. J. 1984, 5, 265-273. [CrossRef]

82. Chong, H.G. Measuring performance of small-and-medium sized enterprises: The grounded theory approach. J. Bus. Public Aff. 2008, 2, 1-10.

83. De Massis, A.; Kotlar, J.; Campopiano, G.; Cassia, L. The impact of family involvement on SMEs' performance: Theory and evidence. J. Small Bus. Manag. 2015, 53, 924-948. [CrossRef]

84. Lonial, S.C.; Carter, R.E. The Impact of Organizational Orientations on Medium and Small Firm Performance: A Resource-Based Perspective. J. Small Bus. Manag. 2015, 53, 94-113. [CrossRef]

85. Gronum, S.; Verreynne, M.L.; Kastelle, T. The role of networks in small and medium-sized enterprise innovation and firm performance. J. Small Bus. Manag. 2012, 50, 257-282. [CrossRef]

86. Kaplan, R.S.; Norton, P.D. The Balanced Scorecard-Measures That Drive Performance. Harv. Bus. Rev. 1992, 70, 71-79. [PubMed]

87. Ismail Salaheldin, S. Critical success factors for TQM implementation and their impact on performance of SMEs. Int. J. Product. Perform. Manag. 2009, 58, 215-237. [CrossRef]

88. Keh, H.T.; Nguyen, T.T.M.; Ng, H.P. The effects of entrepreneurial orientation and marketing information on the performance of SMEs. J. Bus. Ventur. 2007, 22, 592-611. [CrossRef]

89. Herche, J.; Engelland, B. Reversed-polarity items and scale unidimensionality. J. Acad. Mark. Sci. 1996, 24, 366. [CrossRef]

90. Pallant, J. SPSS Survival Manual: A Step by Step Guide to Data Analysis Using SPSS for Windows (Versions 10 and 11): SPSS Student Version 11.0 for Windows; Open University Press: Milton Keynes, UK, 2001.

91. Fombrun, C.J.; Gardberg, N.A.; Sever, J.M. The Reputation QuotientSM: A multi-stakeholder measure of corporate reputation. J. Brand Manag. 2000, 7, 241-255. [CrossRef]

92. Jaworski, B.J.; Kohli, A.K. Market orientation: Antecedents and consequences. J. Mark. 1993, 57, 53-70. [CrossRef]

93. Moore, G. Corporate Social and Financial Performance: An Investigation in the U.K. Supermarket Industry. J. Bus. Ethics 2001, 34, 299-315. [CrossRef]

94. Casillas, J.C.; Moreno, A.M. The relationship between entrepreneurial orientation and growth: The moderating role of family involvement. Entrep. Reg. Dev. 2010, 22, 265-291. [CrossRef]

95. Mwaura, S.; Carter, S. Does Entrepreneurship Make You Wealthy? Enterprise Research Centre: Birmingham, UK, 2015.

96. Wang, L.; Juslin, H. Values and corporate social responsibility perceptions of Chinese University Students. J. Acad. Ethics 2012, 10,57-82. [CrossRef]

97. Elias, R.Z. An examination of business students' perception of corporate social responsibilities before and after bankruptcies. J. Bus. Ethics 2004, 52, 267-281. [CrossRef]

98. Dwyer, S.; Richard, O.C.; Chadwick, K. Gender diversity in management and firm performance: The influence of growth orientation and organizational culture. J. Bus. Res. 2003, 56, 1009-1019. [CrossRef]

99. Ringle, C.M.; Wende, S.; Becker, J.-M. SmartPLS 3. Boenningstedt: SmartPLS GmbH. Available online: http:/ / www.smartpls.com (accessed on 6 June 2017).

100. Henseler, J.; Ringle, C.M.; Sinkovics, R.R. The use of partial least squares path modeling in international marketing. In New Challenges to International Marketing; Emerald Group Publishing Limited: Bingley, UK, 2009; pp. 277-319.

101. Hair, F.J.; Black, W.C.; Babin, B.J.; Anderson, R.E.; Tatham, R.L. Multivariate Data Analysis; Prentice Hall: Upper Saddle River, NJ, USA, 2014; p. 115. 
102. Fornell, C.; Larcker, D.F. Evaluating structural equation models with unobservable variables and measurement error. J. Mark. Res. 1981, 18, 39-50. [CrossRef]

103. Vandenberg, R.J.; Lance, C.E. A review and synthesis of the measurement invariance literature: Suggestions, practices, and recommendations for organizational research. Organ. Res. Methods 2000, 3, 4-70. [CrossRef]

104. Hernández-Perlines, F. Entrepreneurial orientation in hotel industry: Multi-group analysis of quality certification. J. Bus. Res. 2016, 69, 4714-4724. [CrossRef]

105. Henseler, J.; Ringle, C.M.; Sarstedt, M. Testing measurement invariance of composites using partial least squares. Int. Mark. Rev. 2016, 33, 405-431. [CrossRef]

106. Akter, S.; D'Ambra, J.; Ray, P. An evaluation of PLS based complex models: The roles of power analysis, predictive relevance and GoF index. In Proceedings of the 17th Americas Conference on Information Systems (AMCIS2011), Detroit, AL, USA, 4-7 August 2011; Available online: http:/ / ro.uow.edu.au/commpapers / 3126 (accessed on 13 July 2017).

107. Garson, G.D. Partial Least Squares: Regression and Structural Equation Models; Statistical Publishing Associates: Asheboro, NC, USA, 2016.

(C) 2017 by the author. Licensee MDPI, Basel, Switzerland. This article is an open access article distributed under the terms and conditions of the Creative Commons Attribution (CC BY) license (http://creativecommons.org/licenses/by/4.0/). 